\title{
Demographic profile of children with acute lower respiratory tract infections of age between 2months to 5 years
}

\author{
Gornale VK ${ }^{1}$, Minarey $\mathbf{N}^{2}$, Chhina $\mathrm{AS}^{3}$, Katwe $\mathrm{N}^{4}$, Harsha $\mathrm{PJ}^{5}$, Iyer $\mathrm{C}^{6}$ \\ ${ }^{1}$ Dr. Vinod Kumar Gornale, MBBS, M.D, Assistant Professor, Department of Pediatrics, P.E.S. Medical College, NTR \\ University, Kuppam. A.P. India. ${ }^{2}$ Dr. Naikey Minarey, MBBS, M.D, Senior Resident, Department of Pediatrics, Gandhi \\ Medical college , Bhopal M.P., ${ }^{3}$ Dr. Amitoj Singh Chhina, MBBS, Post Graduate Student, Department of Pediatrics, \\ M.V.J. Medical College And Research Hospital Hoskote, Bengaluru, ${ }^{4}$ Dr.Nagendra Katwe, MBBS, M.D, Professor, \\ Department of Pediatrics, P.E.S.Medical College, NTR University, Kuppam. A.P. India, ${ }^{5}$ Dr. Harsha P.J, MBBS, M.D, \\ Assistant Professor Department of Pediatrics, P.E.S. Medical College, NTR University, Kuppam. A.P. India. \\ ${ }^{6}$ Dr.Chandrakala Iyer, MBBS, M.D, Assistant Professor Department of Pediatrics, P.E.S. Medical College, NTR \\ University, Kuppam. A.P. India.
}

Addres for Correspondence: Dr. Vinod Kumar Gornale, MBBS, M.D, Assistant Professor, Department of Pediatrics, P.E.S. Medical College, NTR University, Kuppam. A.P. India.

\begin{abstract}
Background: Acute respiratory infections are a leading cause of morbidity and mortality in under-five children in developing countries. Hence, the present study was undertaken to study the various demographic risk factors which predispose to acute lower respiratory tract infections (ALRI) in children aged 2 month to 5 year. Objective; Demographic factors associated with acute lower respiratory tract infections in children aged 2 months to 5 years. Methods: 100 ALRI cases fulfilling WHO criteria for pneumonia, in the age group of 2 month to 5 years were evaluated for demographic risk factors and clinical profile as per a predesigned proforma in a rural medical college. Results: Sociodemographic risk factors like parental illiteracy, overcrowding, partial immunisation and low socioeconomic status were potential risk factors; similarly nutritional risk factors like early and late weaning, anaemia and malnutrition were associated with ALRI. Significant environmental risk factors were use of biomass fuels, inadequate ventilation at home, and lack of separate kitchen. Conclusion: The present study has identified various socio-demographic, nutritional and environmental risk factors for ALRI which can be tackled by effective health education of the community and effective training of peripheral health personnel.
\end{abstract}

Keywords: Pnemonia, Respiratory Infections, Under-five children

\section{Introduction}

Acute Lower Respiratory Tract Infection (ALRI) is the leading cause of under-5 childhood morbidity in the world, with nearly 156 million new episodes each year, of which India accounts for a bulk of 43 million. The mortality burden is 1.9 million per year, out of which India accounts for around four hundred thousand deaths per year[1]. Among all the children diagnosed with ALRI, $7-13 \%$ are severe enough to require hospital admission [2,3]. The incidence of pneumonia in developed countries is 3-4 percent, its incidence in developing countries ranges between 20 to 30 percent,

Manuscript received: $10^{\text {th }}$ Aug 2015

Reviewed: $16^{\text {th }}$ Aug 2015

Author Corrected; $9^{\text {th }}$ Sept 2015

Accepted for Publication: $19^{\text {th }}$ Sept 2015 this difference could be due to various demographic factors which predispose these children.The present study has been carried to identify various demographic factors associated with acute lower respiratory tract infections in children aged 2 months to 5 years.

\section{Methodology}

After obtaining clearance from ethical clearance committee present prospective study of conducted at MVJ Medical College and Research Hospital, Bengaluru from January 2011 TO December 2011. Children in the age group of 2 months to 5 year admitted with ALRI during the study period were enrolled in the study as cases. A case of ALRI is 
defined as per ARI Control Programme [4] as "presence of cough with fast breathing of more than $60 / \mathrm{min}$ in less than 2 month of age, more than 50/min in 2 month to 12 month of age and more than 40/min in 12 month to 5 year of age, the duration of illness being less than 30 days". The presence of lower chest wall indrawing was taken as evidence of severe pneumonia. The presence of refusal of feeds, central cyanosis, lethargy or convulsions was taken as evidence of very severe pneumonia. Verbal, informed consent of the child's carer was obtained. A detailed history and physical examination was done according to a predesigned proforma to elicit various potential risk factors and other relevant history. Age of the child was recorded in completed months and age of parents in completed year. Routine haematological investigations were done in all cases to know the degree of anaemia and blood counts; chest $\mathrm{x}$ ray was done in all cases to categorise the ALRI into clinical entities and to detect complications, if any. Other specific investigations were done as per requirement in individual cases and all the cases were treated as per the standard protocol depending on the type of ALRI.

\section{Analysis}

After entering the data in Excel sheet Chi square test was used for analysis and "p" value $<0.05$ was taken as significant

\section{Results}

Of 100 cases studied majority were infants (61\%). Males outnumbered females with sex ratio of $1.3 ; 1$. Most of parents were educated till primary or middle school (father $49 \%$, mother $57 \%$ ) and about $22 \%$ of parents were illiterate which was statistically significant. Of the ALRI cases studied, 50\% were incompletely immunized for age. Occurrence of overcrowding among the ALRI cases was 70\%. Among the cases studied, 52\% belonged to families falling under Low Socioeconomic status (class 4 and 5) and significant association was found between socioeconomic status and ALRI severity.

Table- 1: Association between Social factors and Acute lower respiratory Infections

\begin{tabular}{|c|c|c|c|c|c|c|}
\hline & & Pneumonia & $\begin{array}{c}\text { Severe } \\
\text { pneumonia }\end{array}$ & $\begin{array}{c}\text { V. severe } \\
\text { pneumonia }\end{array}$ & Number & $P$ value \\
\hline \multirow[t]{2}{*}{ Age } & 2-12 months & 10 & 34 & 17 & 61 & \\
\hline & 13-60 months & 6 & 26 & 7 & 39 & \\
\hline \multirow[t]{2}{*}{ Sex } & Male & 9 & 34 & 14 & 57 & \\
\hline & Female & 7 & 26 & 10 & 43 & \\
\hline \multirow{4}{*}{$\begin{array}{l}\text { Fathers } \\
\text { Education } \\
\text { status }\end{array}$} & Illiterate & 1 & 8 & 7 & 16 & \multirow[t]{4}{*}{$\mathrm{p}=0.001$} \\
\hline & $\begin{array}{l}\text { Primary/middle } \\
\text { school }\end{array}$ & 4 & 38 & 7 & 49 & \\
\hline & High school/ PUC & 9 & 14 & 7 & 30 & \\
\hline & Graduate & 2 & 0 & 3 & 5 & \\
\hline \multirow{4}{*}{$\begin{array}{l}\text { Mothers } \\
\text { Education } \\
\text { status }\end{array}$} & Illiterate & 2 & 12 & 8 & 22 & \multirow[t]{4}{*}{0.015} \\
\hline & $\begin{array}{l}\text { Primary/middle } \\
\text { school }\end{array}$ & 6 & 40 & 11 & 57 & \\
\hline & High school/ PUC & 7 & 8 & 5 & 20 & \\
\hline & Graduate & 1 & 0 & 0 & 1 & \\
\hline \multirow{2}{*}{$\begin{array}{l}\text { Over } \\
\text { crowding }\end{array}$} & Present & 12 & 38 & 20 & 70 & \multirow[b]{2}{*}{0.744} \\
\hline & Absent & 4 & 22 & 4 & 30 & \\
\hline \multirow{2}{*}{$\begin{array}{l}\text { Smoking in } \\
\text { family }\end{array}$} & Present & 3 & 14 & 8 & 25 & \\
\hline & Absent & 13 & 46 & 16 & 75 & \\
\hline \multirow{2}{*}{$\begin{array}{l}\text { URTI in } \\
\text { family }\end{array}$} & Present & 6 & 16 & 8 & 30 & \multirow[b]{2}{*}{0.646} \\
\hline & Absent & 10 & 44 & 16 & 70 & \\
\hline \multirow{2}{*}{$\begin{array}{l}\text { Immunisation } \\
\text { for age }\end{array}$} & Complete for age & 16 & 22 & 12 & & \multirow[b]{2}{*}{0.0001} \\
\hline & $\begin{array}{ll}\text { Incomplete for } \\
\text { age }\end{array}$ & 0 & 38 & 12 & 50 & \\
\hline
\end{tabular}


Among social factors parents education status (fathers $\mathrm{p}=0.001$, mothers $=0.015$ ), immunisation status $(\mathrm{p}=0.0001)$ were significantly associated with severity of lower respiratory infections.

Table 2: Association between Environmental factors and Acute lower respiratory Infections

\begin{tabular}{|c|c|c|c|c|c|c|}
\hline & & Pneumonia & Severe & V. severe & Number & P value \\
\hline & & & pneumonia & pneumonia & & \\
\hline \multirow[b]{2}{*}{ Ventilation } & Adequate & 4 & 28 & 8 & 60 & \multirow[b]{2}{*}{0.217} \\
\hline & Inadequate & 12 & 32 & 16 & 40 & \\
\hline \multirow[b]{2}{*}{ Lighting } & Electricity & 3 & 26 & 4 & 67 & \multirow[b]{2}{*}{0.027} \\
\hline & (biomass fuels) & 13 & 34 & 20 & 33 & \\
\hline \multirow[b]{2}{*}{$\begin{array}{l}\text { Fuel for } \\
\text { cooking }\end{array}$} & Gas & 12 & 18 & 10 & 40 & \multirow[b]{2}{*}{0.005} \\
\hline & $\begin{array}{l}\text { Other(firewood, } \\
\text { Cowdug, } \\
\text { kerosene) }\end{array}$ & 4 & 42 & 14 & 60 & \\
\hline \multirow{2}{*}{ Kitchen } & Separate & 7 & 13 & 11 & 31 & \multirow[b]{2}{*}{0.047} \\
\hline & Attached & 9 & 47 & 13 & 69 & \\
\hline \multirow{2}{*}{$\begin{array}{l}\text { Type of } \\
\text { floor }\end{array}$} & Mud/ cow dung & 3 & 12 & 8 & 23 & \multirow[b]{2}{*}{0.384} \\
\hline & Pucca & 13 & 48 & 16 & 77 & \\
\hline
\end{tabular}

Source of lighting $(p=0.027)$, type of fuel used for cooking $(p=0.005)$ and type of kitchen $(p=0.047)$ were the environmental factors significantly associated with severity of lower respiratory infections.

Table 3: Association of Nutritional factors with Acute lower respiratory infections.

\begin{tabular}{|c|c|c|c|c|c|c|}
\hline & & Pneumonia & $\begin{array}{c}\text { Severe } \\
\text { pneumonia }\end{array}$ & $\begin{array}{c}\text { V. severe } \\
\text { pneumonia }\end{array}$ & Total & $P$ value \\
\hline \multirow[t]{2}{*}{ Anaemia } & Present & 5 & 33 & 9 & 47 & \multirow[t]{2}{*}{0.135} \\
\hline & Absent & 11 & 27 & 15 & 53 & \\
\hline \multirow{3}{*}{ Weaning } & $<4$ months & 4 & 16 & 10 & 30 & \multirow[t]{3}{*}{0.649} \\
\hline & 4-6 months & 3 & 12 & 5 & 20 & \\
\hline & $>6$ months & 9 & 32 & 9 & 50 & \\
\hline \multirow{3}{*}{$\begin{array}{l}\text { Socio } \\
\text { Economic } \\
\text { status }\end{array}$} & Class 2 and & 13 & 22 & 13 & 48 & \multirow[t]{3}{*}{0.005} \\
\hline & 3 & & & & & \\
\hline & Class 4 and & 3 & 38 & 11 & 52 & \\
\hline \multirow[t]{2}{*}{ Malnutrition } & Present & 4 & 33 & 9 & 46 & \multirow[t]{2}{*}{0.064} \\
\hline & Absent & 12 & 27 & 15 & 54 & \\
\hline
\end{tabular}

Socioeconomic status of parents $(\mathrm{p}=0.005)$ was significantly associated with severity of lower respiratory infections Early weaning was seen in $30 \%$ and late weaning in $50 \%$ of ALRI cases. Of the ALRI cases, $47 \%$ were anaemic and $46 \%$ were found to be malnourished. No significant association was found between ALRI severity and nutrition status.

Among the ALRI cases, $77 \%$ were found to be living in houses with pucca flooring, $40 \%$ of children houses were inadequately ventilated, kitchens were not separated from the main living area in $69 \%$ of houses. Households of $40 \%$ 
were using gas for cooking, $67 \%$ were found to be living in houses utilizing electricity for lighting and remaining $33 \%$ were living in houses using various biomass fuels for lighting.

Among the ALRI cases $25 \%$ were living in households with at least one smoker family member and $30 \%$ had history of at least one family member having or having had a URI in the preceding 2 weeks.

\section{Discussion}

Of the 100 cases included in the study, $16 \%$ were classified as pneumonia, $60 \%$ as severe pneumonia and $24 \%$ as very severe pneumonia according to the ARI Control Program guidelines.

ARI is an important cause of morbidity in the children. On an average, children below 5 years of age suffer about 5 episodes of ARI per child per year, thus accounting for about 238 million attacks. Consequently, although most of the attacks are mild and self limiting episodes, ARI is responsible for about $30-50$ percent of visits to health facilities and for about 20-40 percent of admissions to hospitals [5]. In our study most of ALRI cases are infants $(61 \%)$, which goes in accordance with previous studies by Savitha et al[6], Yousif et al[7] and Broor et al[8] where infants with ALRI constituted $62.5 \%, 58.4 \%$ and $62.5 \%$ respectively. This age group is particularly susceptible due to waning of maternally conferred immunity towards the latter half of infancy. There was, however, no significant association between age and ALRI severity.

Male children were observed to be the majority among various studies on children under 5 years with ALRI. Male children constituted $64.42 \%, 65.8 \%$ and $73.1 \%$ in the studies by Savitha et al[6], Yousif et al[7] and Broor et al[8] respectively. Our study showed similar results with $57 \%$ males among the cases studied. The reason behind this may be that male children are generally cared for more and thus brought earlier and more often for treatment. There was no significant association between sex and ALRI severity

Parental literacy may extend a protective effect on children and thus guard against ALRI by increasing awareness about preventive practices and early medical consultation. Savitha et al[6],with $63.49 \%$ maternal illiteracy and paternal illiteracy of $59.6 \%$ showed strong association between the parents illiteracy and the occurrence of ALRI.

In our study $22 \%$ of mothers and $16 \%$ of fathers were illiterate, and this result was similar to the studies by Yousif et al[7] and Brooret al[8]. Significant association was found between parent's literacy and ALRI severity.
The preventive role of immunisation in ALRI prevention has been stressed upon extensively. The present study shows $50 \%$ were partially immunised children, and this is higher than the Savitha et al[6] and Yousif et al[7] studies which showed $21.15 \%$ and $38.2 \%$ partially immunised children respectively. However, the Broor et al[8] study showed a strong correlation with a higher value of partially immunised children (69\%). Highly significant association was found between immunisation status and ALRI severity

The spread of infection via respiratory droplets may be aggravated by overcrowding. In our study $70 \%$ cases were associated with overcrowding, which is similar to the results of Yousif et al[7] (71.6\%). Savitha et al[6] and Sikolia et al[9] studies showed that slightly more cases are associated with overcrowding, that is, $91.35 \%$ and $80.87 \%$ respectively. However, no significant association was found between overcrowding and ALRI severity. The spread of infection via respiratory droplets may be aggravated by overcrowding.

The present study showed $52 \%$ of children belonged to households falling under low socioeconomic status. Savitha et al [6] have reported significantly more (93.27\%) children from low socioeconomic status. Similar results were found by Cunha et al[10]. Significant association was found between socioeconomic status and ALRI severity. Low socioeconomic status probably limits awareness of care practices and access to material resources, thereby increasing the risk of infections.

Another risk factor studied was upper respiratory tract infections (URI) in other family members within the past 2 weeks and was present in as much as $30 \%$ of the cases. Similar results were found in the study by Broor et al [8](40\%). But, Savitha et al[6] showed less (9\%) cases associated with family history of upper respiratory tract infection. No significant association was found between URI history in the family and ALRI severity.

Breastfeeding confers protective benefits upon the child in the form of transferred maternal anti-infective factors 
that guard against severe microbial disease. Savitha et al[6] and Broor et al[8] studies showed that early weaning i.e. before 4 months of age in $37.5 \%$ and $39.4 \%$ of childrens and late weaning i.e. after 6 months of age in $20.19 \%$ and $27.4 \%$ respectively were significantly associated with ALRI. In this study, 30\% of the cases had early weaning and $50 \%$ had late weaning. There was no significant association between weaning age and ALRI severity.

Anaemia was a significant risk factor for ALRI in study done by Ramakrishnan et al[11] (74\%) . But, our study shows $47 \%$ of cases associated with anaemia, which is similar to the Shah et al[12] study (55\%) but less when compared to other studies. No significant association was found between anaemia and ALRI severity Malnutrition causes children to have defective cellmediated immunity secondary to thymolymphatic depletion leading to Gram-negative bacterial infections and sepsis and the period of infection is prolonged. Malnutrition was found in $46 \%$ of ALRI cases in our study,similar to Broor et al[8] (40.1\%).

However, Savitha et al[6] showed more cases (62.71\%) associated with malnutrition and Yousif et al[7] reported malnutrition in only $19 \%$ of cases. No significant association was found between nutrition status and ALRI severity, and this was in accordance with the findings of Yousif et al[7].

Inadequate ventilation tends to accentuate the effect of the indoor air pollutants as proper egress from the house is not possible.In our study $40 \%$ of cases did not have adequate ventilation in their house. This was similar to the findings of Savitha et al[6], in which only $32.7 \%$ cases did not have adequate ventilation in their house. No significant association was found between ventilation and ALRI severity.

Biomass fuels are widely used in households in developing countries, these are burnt in simple stoves with incomplete combustion generating a lot of toxic products that adversely affect specific and non specific local defence mechanisms of the respiratory tract. Young children, particularly under 5 years, are at great risk due to longer stay indoors and close proximity to mother during cooking $[8,13]$.

The majority of the cases in our study (60\%) lived in houses where biomass fuels like firewood, cow dung, kerosene were used as fuel for cooking, which is similar to the Sikolia et al[9] (71.2\%) study. But, Savitha et al[6] reported that biomass fuels were used more often (98\%) for cooking. Significant association was found between cooking fuel and ALRI severity.

The main mode of light source used is electricity (67\%) in our study. Other sources like kerosene lamps and biomass fuels comprised 33\%. The Savitha et al[6] study reported similar results with $66 \%$ using electricity. But, the study by Sikolia et al[9] reported the main mode of light source as kerosene lamp (93.88\%).

Significant association was found between lighting source and ALRI severity. Kerosene lamps emit harmful hydrocarbon particulate matter, which, due to a size smaller than $2.5 \mu$ can penetrate deep into the lungs, thereby increasing the risk of lower respiratory infection[14].

A majority of the of cases $(69 \%)$ in our study did not have a separate kitchen and cooking was done in the living place, leading to the bulk of emissions being released into the living area, which is similar to the findings of Sikolia et al[9] (69.85\%). However, Savitha et al[6] reported that $85.55 \%$ had a separate kitchen. Significant association was found between kitchen type and ALRI severity.

Environmental tobacco smoke is an indoor pollutant that reduces local defence mechanisms and predisposes children to ALRI. In the present study family history of smoking was seen in $25 \%$ of cases. Similar findings were reported by Broor et al[5] (32.8\%) and van Gageldonk-Lafeber et al[15](35\%).

But, Savitha et al[6], showed $73.08 \%$ of cases had family history of smoking. No significant association was found between ALRI severity and smoking in the family.

\section{Conclusion}

Socio-demographic risk factors like parental illiteracy, overcrowding, partial immunisation and low socioeconomic status were potential risk factors; similarly nutritional risk factors like early and late weaning, anaemia and malnutrition were associated with ALRI. Significant environmental risk factors were use of biomass fuels, inadequate ventilation at home, and lack of separate kitchen.

Funding: None

Conflict of Interest: None 


\section{References}

1. Rudan I, Boschi-Pinto C, Biloglav Z, Mulholland K, Campbell H. Epidemiology and etiology of childhood pneumonia. Bull World Health Organ. 2008 May;86(5):408-16.

2. Rudan I, Tomaskovic L, Boschi-Pinto C, Campbell H and WHO Child Health Epidemiology Reference Group. Global estimate of the incidence of clinical pneumonia among children under five years of age. Bull World Health Organ. 2004 Dec; 82(12): 895-903.

3. WHO Weekly Epidemiological Record 15 February 2008, vol. 83, 7 (pp 61-68).

4. World Health Organization Programme for the Control of Acute Respiratory Infections. Acute respiratory infections in children: case management in small hospitals in developing countries: a manual for doctors and other senior health workers (WHO/ARI/90.5). Geneva: WHO, 1990.

5. WHO. Health situation in the South-East Asia Region 1994-1997, Regional Office for SEAR,New Delhi, 1999.

6._Savitha MR, Nandeeshwara SB, Pradeep Kumar MJ, ul-Haque F, Raju CK. Modifiable risk factors for acute lower respiratory tract infections. Indian J Pediatr. 2007 May;74(5):477-82.

7. Yousif TK, Khaleq BANA. Epidemiology of acute lower respiratory tract infections among children under five years attending Tikrit general teaching hospital. Middle eastern J Fam Med. 2006; 4(3):48-51.

8. Broor S, Pandey RM, Ghosh M, Maitreyi RS, Lodha R, Singhal T, Kabra SK. Risk factors for severe acute lower respiratory tract infection in under-five children. Indian Pediatr. 2001 Dec;38(12):1361-9.

9. Sikolia D N, Mwololo K, Cherop H, Hussein A. The prevalence of acute respiratory infections (ARI) and the associated risk factors; A study of children underfive years of age in Kibera Lindi village,Nairobi, Kenya, J Natl Inst Public Health,2002:51(1):67-72.

10. Cunha AL, Margolis PA, Wing S. Community economic development and acute lower respiratory infection in children. World Health Popul. 2001;2001:17588.

11. Ramakrishnan K, Harish PS. Hemoglobin level as a risk factor for lowerrespiratory tract infections. Indian $\mathbf{J}$ Pediatr. 2006 Oct;73(10):881-3.

12. Shah N, Ramanakutty V, Premila PG, Sathy N. Risk factors for severe pneumonia in children in south Kerala: a hospital based case control study. J Trop Pediatr. 1994;40:201-6.

13. Smith KR, Sarnet TM, Romieu I, Bruce N. Indoor air pollution in developing countries and acute lower respiratory infection in children. Thorax. 2000;55:51832.

14. Sharma S, Sethi GR, Rohtagi A, Chaudhary A, Shankar R, Bapna JS, Joshi V, Sapir DG. Indoor air quality and acute lower respiratory infection in Indian urban slums. Environ Health Perspect. 1998 May;106(5):291-7.

15. van Gageldonk-Lafeber AB, van der Sande MA, Heijnen ML, Peeters MF, Bartelds AI, Wilbrink B. Risk factors for acute respiratory tract infections in generalpractitioner patients in The Netherlands: a casecontrol study. BMC Infect Dis. 2007 Apr 27;7:35.

\section{How to cite this article?}

Gornale VK, Minarey N, Chhina AS, Katwe N, Harsha PJ, Iyer C. Demographic profile of children with acute lower respiratory tract infections of age between 2months to 5 years. Pediatr Rev: Int J Pediatr Res 2015;2(3):15-20.doi: 10.17511/ijpr.2015.i03.03 